\title{
Intervention Of Nurse Deficit Self Care In The Skizofrenia Patient: Systematic Review
}

\author{
Rosmini, Eny Sutria, Wahdaniah \\ UIN Alauddin Makassar, Indonesia \\ Corresponding author: rosmini.minhy02@gmail.com
}

\begin{abstract}
Background: Schizophrenia is one of the disorders in the brain that causes difficulties in processing information, solving problems and interpersonal relationships, due to interference with brain function. Patients who experience mental disorders, especially patients with schizophrenia, have decreased while doing the Daily Living Activity (ADL) because of apathy and loss of motivation means loss of interest and energy in life. This causes the patient to experience a decrease in productivity. Schizophrenia in an apathetic state experiences the disruption of daily activities such as brushing teeth, combing hair, bathing, dressing / dressing up or ignoring eccentric neatness or ignoring hygiene so intervention is needed to overcome the problems experienced.

Purpose: This study aimed to find out how nursing interventions self-care deficits in schizophrenic patients.

Methods: The design of this research is quantitative descriptive with a systematic review approach that has the criteria for reviewing the article carried out in a structured and planned manner.

Results: Research results from the six journals analyzed nursing interventions for self-care deficits in schizophrenic patients improve personal hygiene.

Conclusion: The results of this study indicate that nursing interventions for self-care deficits in schizophrenic patients are supportive group therapy, daily schedule of activities, health education, group activity therapy, motion rehabilitation, and motivation for group art therapy.
\end{abstract}

Keywords: Self-Care Deficits, Nursing Interventions, Schizophrenia 


\section{Journal Of Nursing Practice}

http://thejnp.org

ISSN: 2614-3488 (print); 2614-3496 (online)

Vol.3 No.2. April 2020. Page.244-252

\section{BACKGROUND}

Schizophrenia is one of several diagnoses in mental disorders and is a severe mental disorder. Schizophrenia is a collection of several symptoms or disease processes that affect perception, emotions, behavior, cognition, and social functions, but schizophrenia affects each individual in different ways. Schizophrenia can have an impact on life in patients, communities and families (Wati, 2018).

Schizophrenia is a group of cycotic disorders, with basic disorders of personality, distortions typical of thought processes. Schizophrenia disorders, generally characterized by distortion of thoughts and perceptions that are fundamental and distinctive, distortion of the mind, and affect that is not harmonious or blunt. Based on data released by the World Health Organization (WHO) 2019, psychiatric patients with the most diagnoses are schizophrenia of approximately 24 million people worldwide. Of the 24 million people, in Indonesia there were 1,928,663 million with Schizophrenia (RISKESDAS, 2018).

The phenomenon of schizophrenia in Indonesia is always increasing every year. According to the World Health Organization, in 2014 the number of schizophrenics around the world was more than 21 million. In addition, the prevalence of schizophrenia (severe mental disorder) of 1.7 per million nationally. Based on one recent study the prevalence of recurrence in schizophrenics was in the range of 50-92\% globally (Weret \& Mukherjee, 2014). Based on data obtained from 2018 Rikesdas Indonesia experienced an increase in the number of people with mental disorders schizophrenia / psychosis in 2013 as much as $1.7 \%$ increase to $7 \%$ in 2018.

Schizophrenia patients experience a decrease in daily activities due to apathy and loss of motivation means loss of interest and energy in life. This makes patients less energy to carry out daily activities, they are usually only able to do eating and sleeping activities. Disruption of daily activities of schizophrenic patients is caused by apathetic conditions experienced so that they do not care about neatness / dressing or dressing, bathing, brushing teeth, and combing hair (Hastuti and Rohmat, 2018).

Decreased client motivation to perform self-care or personal hygiene namely bathing, eating, decorating, defecating and urinating causes patients to deficit self-care in performing care. Therefore, nurses must intervene nursing patients with schizophrenia to conduct self-care. With nursing interventions that are continuously carried out by nurses, patients can be independent in performing self-care or personal hygiene.

According to Yudhana (2017), patients want to do self-care when told to do things such as bathing, decorating and changing clothes by their nurses and clients say they don't know about self-care so that patients with mental disorders or schizophrenia experience self-care deficits.

With the nursing intervention provided by nurses to schizophrenic patients who experience self-care deficits can improve personal hygiene or patients want to do personal hygiene independently. Therefore according to researchers how important self-care so researchers are interested in knowing nursing interventions self-care deficits in schizophrenic patients.

\section{OBJECTIVE}

This study aimed to find out how nursing interventions self-care deficits in schizophrenic patients 


\section{Journal Of Nursing Practice}

http://thejnp.org

ISSN: 2614-3488 (print); 2614-3496 (online)

Vol.3 No.2. April 2020. Page.244-252

\section{METHODS}

This research uses a quantitative descriptive design with a systematic review approach. This study uses a systematic review approach to determine nursing interventions for self-care deficits in schizophrenic patients. Literature search through a database: Google scholar, Pubmed, Science direct and Portal Garuda.

The inclusion and exclusion criteria in this study are the inclusion criteria: Articles for 2015-2018, Articles that fit the topic, Journals published domestically and abroad, Journals that use English and Indonesian, Journals that are ISSN or doi while the exclusion criteria are: articles that are double publication and articles that are not in accordance with the research objectives.

After collecting data and information, all of the data and information is selected by using Duffy's Research Appraisal Checklist Approach with the problem being examined. To present the problem to be discussed, the collected data was analyzed descriptively

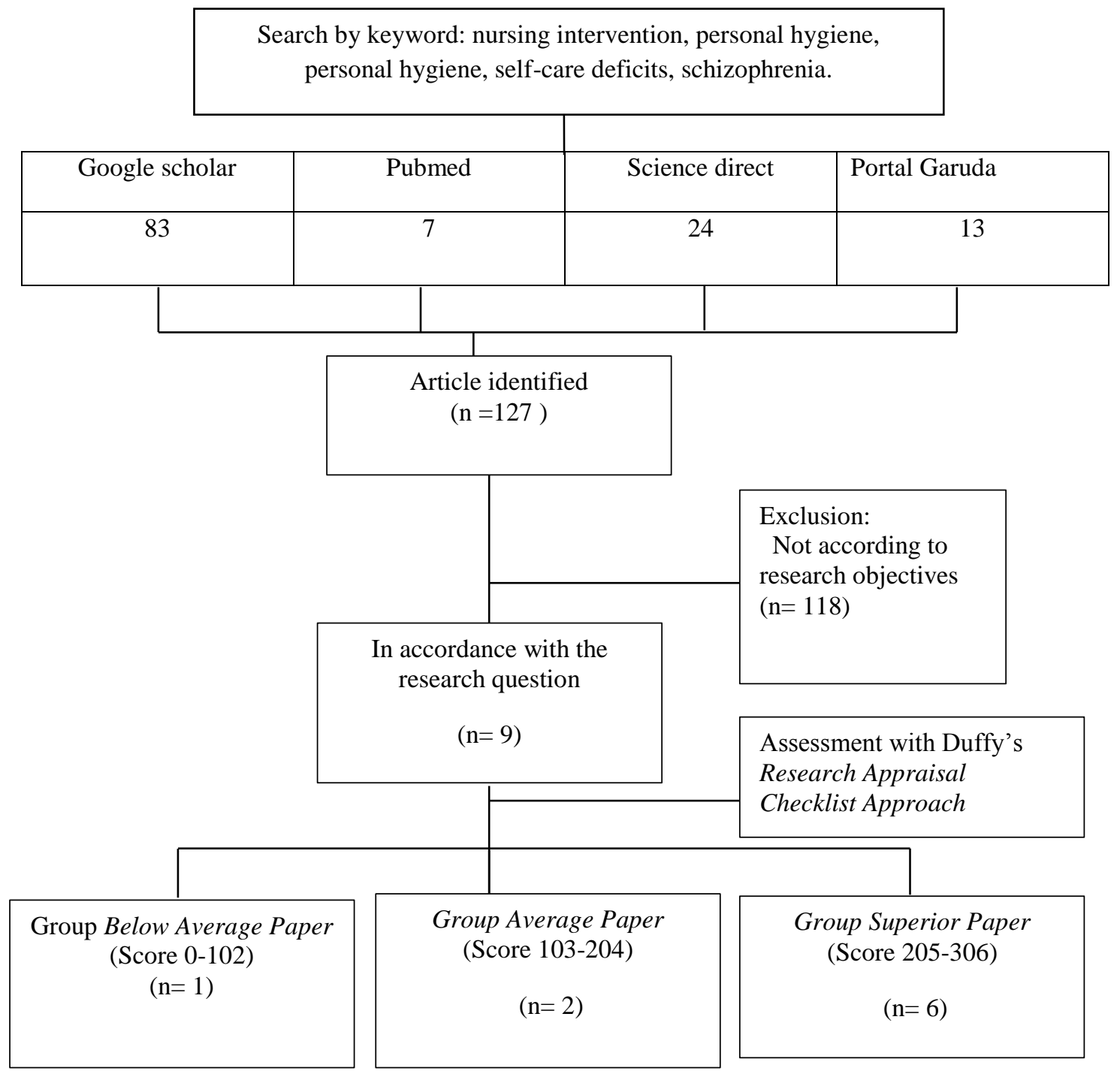

Figure 1. Flowchart for selection and inclusion

Inclusion article

$$
(n=6)
$$




\section{Journal Of Nursing Practice}

http://thejnp.org

ISSN: 2614-3488 (print); 2614-3496 (online)

Vol.3 No.2. April 2020. Page.244-252

\section{RESULTS}

Based on the total papers reviewed 127 were obtained from search and evaluation strategies. Out of 127 papers, 120 articles were excluded because they were not in line with the objectives of the study. So there are 6 that fit the inclusion criteria and then are assessed by Duffy's Research Appraisal Checklist Approach. And 6 journals that fall into the Supporior Paper category (Score 205-306).

\section{DISCUSSION}

From the results of several studies on nursing interventions self-care deficit in schizophrenic patients, shows that with the nursing interventions applied by nurses to schizophrenia clients patients can do personal hygiene correctly or patients want to do personal hygiene against themselves.

According to research conducted by Emilyani (2010), it shows that the influence of supportive group therapy on the independence of schizophrenic patients who experience self-care deficits. With the supportive group therapy performed by nurses, the patient can perform personal hygiene independently. In this study it can be seen that the patient's independence before supportive therapy for self-care: bathing, most of the $55.5 \%$ of respondents were able to help. To perform self-care: Dress up / Make up, most (44.5\%) of respondents have not been able to do self-care. For Personal Care: eating and drinking mostly 55.5\% are able to do without assistance. As for self-care: Defecation / defecation, most respondents $55.5 \%$ were able to do it with assistance.

Supportive group therapy plays a role in increasing self-care deficit self-care schizophrenia patients who experience self-care deficit problems, through a group support system and facilities and an effort to provide group members who contribute to each other and provide support for each other related to self-care deficit problems faced by patients

Subsequent research was conducted by Hastuti and Rahmat (2018), the results of which showed that there was an influence on the implementation of daily self-care schedules on the level of self-care independence in schizophrenic patients. Schedule selfcare activities such as bathing, shampooing, nail cutting, brushing teeth, dressing and dressing up. With the making of a schedule patients can be trained in self-care and implementation time can be organized.

This study shows that after the implementation of the daily self-care schedule, the level of independence of self-care in schizophrenic patients has increased, the value before the implementation of the daily self-care schedule is $15,55 \%$ and after the implementation of the daily self-care schedule $6,45 \%$. Evidenced by the results of tests with t-test that showed a value of $p=0,000(\alpha<0,05)$ and a value of $t=16,709$ with a mean value of 9 , 200 then Ha is accepted and Ho is rejected.

This is in line with research conducted by Laili (2014), in a study entitled "The Effect of Independent Activities: Personal Hygiene Against the Self-Deficiency Patients Self-Care Deficits in Mental Disorders Patients". The results showed that there was a significant influence between independent activities: personal hygiene on the independence of DPD patients.

Schizophrenia patients experience a decrease in daily activities, especially in selfcare because loss of motivation and apathy means loss of energy and interest in life. This makes the patient lazy, they cannot do anything else other than sleep and eat. Apathetic conditions in schizophrenia cause disruption of daily routine activities such as bathing, combing hair, brushing teeth and not caring about neatness or dressing / dressing up. 
With the scheduling of daily self-care activities, schizophrenia patients can be trained in self-care. Activities undertaken daily can reduce feeling lazy in schizophrenic patients (Suhita, 2020).

Subsequent research by Madalise (2015) showed the effect of providing health education on mental patients with dental and oral hygiene. The results of this study respondents who have been given health education about how to brush teeth properly and correctly indicate that the implementation of ADL has increased. Where the average implementation of ADL before the provision of health education is 1:00 and the average implementation of ADL after 1, 50. This is also evident from the results of statistical analysis using the Wilcoxon sigend rank test obtained $\mathrm{p}$ value $=0.00000<\alpha=0,05$ at a significant level of $95 \%$ or a significance level of $5 \%$, then Ha is accepted.

Schizophrenic or psychiatric patients need guidance and outside support. So that patients have the ability to care for themselves independently and have a willingness to solve problems, especially personal hygiene problems. Therefore health education regarding self-care in patients with mental disorders or schizophrenia needs to be done. Health education is a dynamic process of behavior change with the aim of changing or influencing human behavior which includes components of knowledge, attitudes, or practices related to healthy living goals both individually and in groups (Notoatmodjo, 2012).

With the health education carried out by nurses, patients can gain knowledge about self-care especially dental and oral health or patients can recall the way of self-care.

The results of the research on the implementation of ADL respondents after being given health education about how to brush teeth properly and correctly showed that the implementation of ADL had increased, namely 15 people $(50 \%)$ were poor and those implementing ADL well were 15 people (50\%). However, there was one respondent whose ADL implementation ability remained before and after he was given health education because the patient's condition at the time of the study showed that the patient was not yet able to independently carry out ADL.

Subsequent research by Sutinah \& Mardiansyah (2017), which shows that group activity therapy (TAK) stimulation of perception influences schizophrenia client's personal hygiene care. The results of this study can be seen by schizophrenia clients who experience self-care deficits before the activity of stimulation group perception therapy is less able to perform self-hygiene care with an average value of 8.05 while the average ability of selfcare self-hygiene after therapy of perceptual stimulation group activity activities obtained values an average of 30.88 . With a p-value of 0,000 which means that there is an effect of providing therapeutic activity of perception stimulation groups on self-care abilities. With the TAK, patients can be motivated to do self-care. The TAK that was carried out consisted of 3 phases, namely the orientation phase, namely giving greetings, evaluating / validating and contracting. Work phase where at this stage the researcher explains about the therapeutic material or TAK that will be done. Termination phase where the researcher conducts subjective, objective evaluations, follow-up plans and contracts with the next meeting. Clients can gradually improve self-care hygiene in daily life. Therapeutic activity group perception stimulation can be divided into 3 sessions.

This is in accordance with the results of research by Sasmita H (2012), conducted at Prof.HB Mental Hospital. Sa'anin Padang where the ability of self-care activities in patients before the token economy method is still low and this is also evidenced by the results of Desty Emilyani's study (2010) conducted at the NTB Mental Hospital where the 


\section{Journal Of Nursing Practice}

http://thejnp.org

ISSN: 2614-3488 (print); 2614-3496 (online)

Vol.3 No.2. April 2020. Page.244-252

level of independence of schizophrenic patients who experience self-care deficits before doing so supportive group therapy is still low with a value of $55 \%$ independence.

Therapeutic group activity is important in the practice of psychiatric nursing for interaction and communication disorders as well as one of the therapeutic skills. Group activity therapy (TAK) is part of modality therapy that seeks to improve psychotherapy with a number of clients at the same time. Group activity therapy has two general goals, namely therapeutic goals and rehabilitative goals.

The therapeutic goals of Group Activity Therapy (TAK) are to facilitate interaction, encourage socialization with the environment (outside relationships with clients), increase stimulus and reality responses of individuals, motivate and encourage affective and cognitive functions, increase feelings of belonging, increase self-confidence, and learn new ways to solve problems. While rehabilitative goals are to improve the ability for selfexpression, increase the ability of empathy, improve social skills, and improve patterns of problem solving (Wuryaningsih, 2018).

The study is in line with Agustin's research (2018) shows the process of evaluating the application of TAK by 25 clients $(65.79 \%)$ clients experienced the largest evaluation improvement in TAK of personal hygiene care (bathing) is a commitment in bathing $2 \mathrm{x}$ per day, as many as 23 clients $(60,53 \%)$ showed the greatest improvement in ability evaluation in TAK of personal hygiene care (tooth brushing) was to explain the benefits of brushing teeth and as many as 30 clients $(78.95 \%)$. The biggest improvement evaluation in the TAK of personal hygiene care (hand washing) is being able to demonstrate proper hand washing.

With the Group Activity Therapy (TAK) the client is motivated to do personal hygiene or maintain personal hygiene. Through TAK schizophrenia clients can improve their personal hygiene.

Subsequent research conducted by Maryatun (2015) showed that there was a relationship between rehabilitation of motion therapy and self care independence in schizophrenic patients. Motion therapy can stimulate the growth of sports neurons in certain areas damaged during depression and eliminate muscle stiffness so that patients are not lazy to move. With the rehabilitation or movement through sports activities carried out at least 2 times a week can increase the enthusiasm and motivation of yourself and others to participate in rehabilitation activities.

In this study, data from 32 respondents who did rehabilitation well were 18 (56.2\%) and respondents who did poor rehabilitation were 14 (43.8\%). Rehabilitation is good, which follows the rehabilitation activities with a frequency of at least 2 times a week on a regular basis, following the rehabilitation stages from the initial heating, core movements to cooling with the stages of preparation, implementation and supervision. In the implementation of rehabilitation of motion therapy the client makes data collection or absenteeism and conducts therapy that is supervised by a nurse in the rehabilitation room.

Motion therapy stimulates the release of the hormone dopamine adrenaline to increase energy in moving activities. In schizophrenic patients, social isolation has decreased energy to move because the energy is focused on thought while energy for psychomotor is reduced. With motion therapy, the dopamine hormone, epinephrine released will stimulate blood circulation, increase the body's metabolism and energy to perform activities including self-care activities.

Subsequent research was conducted by Cho \& Lee (2018), with a total sample of 35 patients. The sample in this study was divided into two groups: 17 patients for the experimental group and 18 patients for the control group. the results showed that the 


\section{Journal Of Nursing Practice}

http://thejnp.org

ISSN: 2614-3488 (print); 2614-3496 (online)

Vol.3 No.2. April 2020. Page.244-252

experimental group participating in the art therapy group program showed improvements in several aspects such as: improvement in negative symptoms, motivation and pleasure, interpersonal relationships, personal hygiene and participation in mental illness programs compared to the control group (who did not participate in motivation interview) so that it can be concluded that motivational interviews using group art therapy are effective in the treatment of negative symptoms of schizophrenia. With the motivation given negative thoughts there is no longer not to do self-care. Motivation with group art therapy consists of 12 themes i.e:

1. Introductory program, name decoration, and self-introduction.

2. The desire to own and throw away

3. Identify strengths

4. The present life you want to see

5. The happiest time

6. Find the strength to change

7. Things that must be left behind

8. Praise experience

9. Collaborative groups paint the identification of preparedness and the consolidation of self-confidence

10. Draw in turns

11. Hope tree

12. Letters written for yourself and gift packages

Different research conducted by Susanti (2015), which aims to identify the relationship between knowledge and motivation to meet the basic needs of mental patients with self-care deficits using descriptive methods using cross-sectional correlation. This research was conducted at PT Tampan Mental Hospital of Riau Province in 33 respondents taken using the total sampling method. The measuring instrument used was a questionnaire that had been tested for validity and reliability. The analysis used was univariate and bivariate analysis using the Chi Square test. The results showed that there was no correlation between respondents' knowledge and self-care deficit with a significance level of 0.05 obtained $p>0.05$ was 0.923 . For motivational factors, it was found that there was no significant relationship between the level of motivation and the level of self-care deficit with a significance level of 0.05 with $p>0.05$ being 1,000 . The results of this study are expected to staff nurses in hospitals can improve the quality of psychomotor patients' ability to perform self-care properly.

\section{CONSLUSSION}

Based on the results of the Systematic Review that has been done about nursing interventions deficit self-care nursing in patients with schizophrenia it can be concluded that nursing interventions by nurses are supportive group therapy, including on the schedule of daily activities, health education with health education by nurses, patients can recall personal neighbors hygine, TAK, motion therapy rehabilitation, and motivational group art therapy can improve personal hygiene in schizophrenic patients. 


\section{Journal Of Nursing Practice}

http://thejnp.org

ISSN: 2614-3488 (print); 2614-3496 (online)

Vol.3 No.2. April 2020. Page.244-252

\section{REFERENCES}

Agustin, I. M., Asti, A. D., \& Sumarsih, T. (2018). Proses Evaluasi Penerapan Terapi Aktivitas Kelompok Stimulasi Persepsi: Defisit Perawatan Diri Pada Klien Gangguan Jiwa Di Panti Rehabilitasi X Kabupaten Wonosobo. Proceeding of The URECOL, 215-220.

Cho, J. M., \& Lee, K. (2018). Effects of motivation interviewing using a group art therapy program on negative symptoms of schizophrenia. Archives of psychiatric nursing, 32(6), 878-884. https://doi.org/10.1016/j.apnu.2018.07.002

Emilyani, D. (2010). Peningkatan Kemampuan Mengendalikan Halusinasi Pada Pasien Skizofrenia Dengan Terapi Aktivitas Kelompok Menggunakan Pendekatan Health Belief Model Di Rumah Sakit Jiwa Propinsi NTB. Poltekkes Mataram.

Hastuti, R. Y., \& Rohmat, B. (2018). Pengaruh Pelaksanaan Jadwal Harian Perawatan Diri Terhadap Tingkat Kemandirian Merawat Diri Pada Pasien Skizofrenia Di Rsjd Dr. Rm Soedjarwadi Provinsi Jawa Tengah. Gaster: Jurnal Kesehatan, 16(2), 177-190. https://doi.org/10.30787/gaster.v16i2.294

Keliat, B.A, dkk. (2016). Keperawatan Jiwa Terapi Aktivitas Kelompok edisi 2, EGC Jakarta.

Laili, D. N., \& Rochmawati, D. H. (2014). Pengaruh Aktivitas Mandiri: Personal Hygiene Terhadap Kemandirian Pasien Defisit Perawatan Diri Pada Pasien Gangguan Jiwa. Jurnal Keperawatan dan Kebidanan.

Madalise, S., Bidjuni, H., \& Wowiling, F. (2015). Pengaruh Pemberian Pendidikan Kesehatan Pada Pasien Gangguan Jiwa (Defisit Perawatan Diri) Terhadap Pelaksanaan Adl (Activity Of Dayli Living) Kebersihan Gigi Dan Mulut Di Rsj Prof. Dr. V. L Ratumbuysang Ruang Katrili. JURNAL KEPERAWATAN, 3(2). 1-8.

Maryatun, S. (2015). Peningkatan kemandirian perawatan diri pasien skizofrenia melalui rehabilitasi terapi gerak. Jurnal Keperawatan Sriwijaya, 2(2), 108-114.

Notoatmodjo S. (2012). Promosi Kesehatan dan Perilaku Kesehatan. Jakarta: PT Rineka Cipta.

RISKESDAS. (2018). Hasil Utama RISKESDAS 2018. Retrieved February 25, 2020, from http://kesmas.kemkes.go.id/assets/upload/dir_519d41d8cd98f00/files/Hasilriskesdas-2018_1274.pdf.

Sasmita, H. (2012). Pengaruh Metode Token Economy Terhadap Aktifitas Perawatan Diri pada Pasien Defisit Perawatan Diri. NERS Jurnal Keperawatan, 8(1), 24-31. https://doi.org/10.25077/njk.8.1.24-31.2012

Suhita, B. M., Kusumawati, P. D., Saputro, H., \& Yusuf, A. (2020). Mechanism of Family-coping in Treating Patient with Schizophrenia Viewed from Factors that Affected it at Public Health Center of Balowerti, Kediri. Medico-legal Update, 20(1), 1231.

Susanti, R., Nauli, F. A., \& Utomo, W. (2015). Hubungan Pengetahuan Dan Motivasi Terhadap Pemenuhan Kebutuhan Dasar Pasien Gangguan Jiwa Dengan Defisit Perawatan Diri. Jurnal Online Mahasiswa (JOM) Bidang Ilmu Keperawatan. 2(1). 863-871.

Sutinah., \& Mardyansyah. (2017). TAK stimulasi persepsi berpengaruh terhadap perawatan kebersihan diri klien skizofrenia. Riset Informasi Kesehatan, 6(2), 108114. https://doi.org/10.30644/rik.v6i2.89

Waty, S. (2018). Analisis faktor yang berhubungan dengan strategi koping pada pasien Skizofrenia di Kota Sungai Penuh Tahun 2017. Indonesian Journal for Health Sciences, 2(1), 26-45. http://dx.doi.org/10.24269/ijhs.v2i1.807 
Weret, Z. S., \& Mukherjee, R. (2014). Prevalence of relapse and associated factors in patient with schizophrenia at Amanuel Mental Specialized Hospital, Addis Ababa, Ethiopia: institution based cross sectional study. International Journal of Interdisciplinary and Multidisciplinary Studies (IJIMS), 2(1), 184-192.

World Health Organization. (2019). Schizophrenia. Retrieved February 25, 2020, from https://www.who.int/news-room/fact-sheets/detail/schizophrenia.

Wuryaningsih, E. W., Windarwati, H. D., Dewi, I., Deviantony, F., Hadi, E. (2018). Buku Ajar Keperawatan Kesehatan Jiwa 1. UPT Percetakan \& Penerbitan, Universitas Jember.

Yudhana, S. A., \& Widodo, A. (2017) Efforts To Increase Personal Hygiene Through Personal Hygiene Motivation On Patient. Diploma Thesis, Universitas Muhammadiyah Surakarta. 